\title{
Spacijalnost Matoševa glasa
}

\begin{abstract}
Pinter Kornelija, Spacijalnost Matoševa glasa (Spaciousness of the Matoš’s Voice). „Poznańskie Studia Slawistyczne” 7. Poznań 2014. Publishing House Science and Innovate, pp. 175-184. ISBN 978-83-63795-79-5. ISSN 2084-3011.

The voice connections observed within the A.G. Matos's poetry establish the poem's space/ the poem's body. The grammar of the speech, grammar of the body and grammar of the poem are connected with the same category - the spaciousness. The insight of the voice metaphors highlights the relationship between the voice, body and space stressing the relationship as a condition of the poem's voice and body existence.
\end{abstract}

Keywords: Antun Gustav Matoš; voice; body; voice metaphor; relationship; spaciousness

\section{Od glasa do tijela: Može li ,đurđic drhtati”, može li ,sreća disati”?}

Nastavljajući se na Plutarhovu priču o čovjeku koji je očerupavši slavuja i našavši na njemu malo mesa, uzviknuo: Ti si samo glas i ništa više!, Mladen se Dolar „,uklanjajući perje značenja koje prekriva glas, razdružujući glas od tijela" usredotočuje ,samo na glas i ništa više”: glas dolazi iz unutrašnjosti, nevidljive, nedokučive, izvlači je na površinu, raskrinkava, pokazuje ono od čega se zazire (Dolar 2009: poleđina knjige). Sigmund Freud opisao je zazorno ${ }^{1}$ kao nešto ,što je trebalo ostati tajno i skriveno, ali je izašlo na vidjelo" (cf. Dolar 2009: 40). Koristeći vlastiti glas, praćeni smo

${ }^{1}$ Drugim riječima, parafrazirajući Juliju Kristevu: da bismo ostali u sigurnim granicama identiteta, nastojimo očuvati zazorno kao nešto što istovremeno mora i postojati i ostati skriveno u sferama preverbalnoga, preimaginarnoga. 
efektom srama, jer glasom drugome pokazujemo pospremljenu intimnost (Vuletić 2007: 107). Taj drugi može odlučivati o značenju glasa ili se na njega oglušiti. Glas usvajamo od drugoga, a potom ga kao višak označitelja ${ }^{2}$ izbacujemo kao „netjelesni dodatak tijelu”. Govoreći o krajnjoj, ekstremnoj formi govora, Vuletić kaže kako se u globalnosti kao važnoj osobini govora vidi općeljudskost glasa:

Globalnost, to sam ja, artikuliranost, to je društvo. Globalnost, to sam ja, moje stajalište, svijet kroz mene, svijet percipiran mojim osjetilima, izražen mojim govorom. Govor mora imati opće elemente (artikuliranost) da bi bio društveno prihvatljiv; ali mora imati i pojedinačne elemente (globalnost) da bi bio ljudski. U ekstremnoj formi govora - u kriku, svi su ljudi braća (Vuletić 2007: 68).

Višak tijela ${ }^{3}$ na sličan način možemo dovesti pod svjetlo tražeći njegove tragove i otiske u jeziku. Tijelo je ishodište jezika, ono nam čita svijet i nanovo vabi na rekonceptualiziranje slike svijeta, razumijevanja sebe, svoga neposrednog okruženja i najšire stvarnosti ${ }^{4}$. Izazovi resemantiziranja, razotkrivanje novih, na temelju već usvojenih značenja koji počivaju u vlastitom iskustvu ili na doživljavanju tuđega, izviru iz odnosa tijela i stvarnih i jezičnih podražaja. Zazivanje tijela, pri korištenju jezičnog alata, dekodirajući jezik prema značenju ili kodirajući značenje u jezične oblike, postaje putom aktualizacije novog značenja. Tražeći iznova kontakt s tijelom, jezik ukazuje na ponovnu upotrebu osjetila, no u drugim prostorima značenja. Posredstvom osjetila, jezika i tijela otvara se mogućnost ponovnog definiranja doživljaja svijeta. Antun Gustav Matoš stvarao je u vremenu u kojem

2 „Tko želi govoriti o «višku značenja» u vizualnoj kulturi našeg doba mora govoriti o «manjku smisla»" (Paić 2009: 278).

${ }^{3} \mathrm{O}$ višku glasa kao o posljedici izravnog prijelaza unutrašnjosti govori Dolar: „Kada koristimo glas mi moć «uvijek-već» prepuštamo Drugome (...). Previše smo izloženi glasu, a glas izlaže previše, unosimo i izbacujemo previše" (Dolar 2009: 78).

4 ,Što je stvarno i što je sadašnjost, prezentnost? Stvarno je tijelo. Kroz njega prolazi vrijeme i mijenja ga. Zatim je stvaran osjećaj. Osjećaj je konkretan kao tijelo, jer ga prate neurotransmiterske, hormonske i druge tjelesne promjene, izmijenjen mišićni tonus, disanje, rad srca, sada, u ovom vremenu. Osjećaj daje prezentu pravu sadašnjost. Možemo pričati o prošlosti ili budućnosti, a one će postati tjelesna, psihološka sadašnjost aktiviranjem emocija: «Slušam vas, čitavo vas vrijeme slušam: prolazite, promičete, tečete... Ali priča sve zaustavlja!»” (Pansini 1985: 42). 
misao o tijelu nije bila kakva je danas, a svojstva i obilježja autobiografskog ,ja" uvelike su uvjetovana socijalnim i kulturalnim okruženjem i njihovim vrijednostima ${ }^{5}$. U „društvu spektakla" ${ }^{6}$ tijelo je izgubilo podrijetlo i čistoću. O Matoševu se jeziku danas, bilo da je ispovijedao sebe sebi, domovini ili ženi, koju god objektivnu stvarnost pokušao dohvatiti, može govoriti kao o jeziku obilježenom subjektivnošću koja neminovno proizlazi iz tjelesnosti.

Iz Matoševe zbirke izabranih pjesama koju je priredio Ivo Frangeš (Matoš 1996) popisali smo imenice koje se odnose na dijelove tijela: usne, oči, grudi, oko, lice, obraz, srce, kostur, čelo, prsa, zjene, ručice, ruka, vrat, zub, kosti, grlo, tijelo, noga, žile, živci, koža, krv, mozak, sise, kosa, njedra, vlasi, krilo, prst, brada, usta.

Sloboda metaforizacije i literarnost svakodnevice vide se u sljedećim Matoševim poetskim preoznačavanjima pojmova koji svojim prvotnim značenjem imaju najužu vezu s tijelom u pjesmi Utjeha kose: „Sve, baš sve je mrtvo: oči, dah i ruke, / (...) Samo kosa tvoja još je bila živa” (Matoš 1996: 54).

Smrt je jezikom do kraja neiskaziva, stoga je izazov. Vladimir Biti, citirajući Ranka Marinkovića, ističe: „Nikada ne uspijevamo potpuno «očistiti» stvari od «suvišnoga», esencijalizirati ih, svesti na čiste funkcije, onako kako nam se javljaju u jeziku, koji nam omogućuje da pripremamo planove sa stvarima i izvodimo simbolične radnje u mislima" (Biti 1994: 31). John Zerzan kritizira sve tekovine civilizacije u kojima najvažniju i najodgovorniju krivicu odvajanja od prirode i stvarnosti vidi u jeziku: „Poput ideologije, jezik svojom moći simbolizacije stvara lažna odvajanja i opredmećenja. Što više mašinerija jezika egzistenciju podvrgava samoj sebi, radeći to opet usporedno s ideologijom, to je skrivenija njezina uloga u reproduciranju društva

5 ,Nisu rijetke tvrdnje da je riječ/pojam tijelo (body) 80-ih godina 20. stoljeća posve istisnulo iz govora temeljne riječi/pojmove metafizičke povijesti - duh i duša. Ako je duh (logos, mind, Geist) ono što stoji u središtu filozofije do njezina kraja u ozbiljenju u pozitivnim znanostima, a riječ duša (psyche, soul, seele) silazak u ono unutarnje, mračno i nespoznatljivo s kojim otpočinje doba psihologije i psihoanalize, tada je tjelesnost tijela svoju ekstazu viška značenja poprimila tek nakon uspostave novoga poretka uspostave društvenih i kulturalnih praksi dokidanja represivne sublimacije svijeta 60 -ih godina 20. stoljeća. Tijelo se artikulira kao niz diskurzivnih praksi. Riječ kao osnova teksta početak je «velike priče» o tijelu u zapadnoj kulturi na ishodu modernosti" (Paić 2009: 270).

${ }^{6}$ Sintagma neomarksističkog teoretičara i umjetnika Guya Deborda (1999). 
potlačivanja" . Neizrecivo, koje se želi iskazati, „živa kosa” kao slika paralelizma živoga i mrtvoga, kao slika, ne kao dadaistička poezija koja izbjegava riječ u aleatoričkoj montaži jezičnih slika, ovdje je tijelo postavljeno u prvi plan svojom smrtnošću koja se ne da iskazati do kraja. Isto se postiže u stihovima pjesme $U$ vrtu: „U mraku žubor, vrelo - slušaj, dušo: / (...) Kroz šiprag hihot vile - miruj, dušo: / (...) U grmu prvi slavuj - ćuti, dušo: / (...) U lijesi prvo cvijeće - diši, dušo: / (...) Tišinom struje, sjene - dršći, dušo: / (...) Kroz zvijezde čežnje, slutnje - umri, dušo: (...)" (Matoš 1996: 27).

Glagoli „slušaj”, „ćuti”, „diši”, „dršći”, „umri” poredani/stupnjevani su u strofama redom tjelesnog umiranja. Kretanje smrti kroz strofe prikazuje se teksturom pokretnih slika. Redoslijed glagola koji upućuju na tjelesnu smrt putokaz je interpretaciji čitave pjesme, pa nesumnjivo daje prostor i za moguće tumačenje smrti i tijela pjesme ${ }^{8}$ kao čina apsolutne gotovosti. Takav redoslijed glagola privlači pozornost.Iako nagovaraju svojim slijedom kako ih razumijevati, oni upućuju i na riječi sasvim suprotnog značenja: „žubor”, „vrelo”, ,izvor”, „život”, „,hihot”, „vile”, ,sreća”, „slavuj”, „srce”, „,cvijeće". Ova konstrukcija u pjesmi može se objasniti kognitivnim modelom gramatike kao slike, a ovdje je upotrijebljena da bi oslikala tjelesnu smrt: udah koji je život i izdah koji je smrt. Postupak predikacije glagola koji se nameće čitatelju Matoševo je povjerenje u sposobnost čitateljske interpretacije - čitanje smrti kroz život tijela. Mihovil Pansini prikazuje komunikaciju u tri sloja: anorganski (kvantno-mehanički, fizikalni i kemijski zakoni), biološki (osjetilnost za vegetabilne funkcije i nagone, putem osjetilnih organa ili čak bez njih, kao taksije i tropizmi), komunikacija u području svijesti, ideja, jezika. Jedan je sloj ugrađen u drugi i oni međusobno surađuju, odnosno nema govora bez senzorike, senzorike bez fizičnosti. Tražeći vezu između anorganskoga i komunikacije, Pansini dolazi do „odnosa” kao ključne točke koja

7 I dalje: „Jezik Navajo Indijanaca smatra se «pretjerano doslovnim» jezikom, zbog pristranosti našeg doba prema općenitom i apstraktnom. Podsjeća nas da je u drevno doba vladalo izravno i konkretno; postojalo je «beskrajno obilje izraza za ono što se dodiruje i vidi». Čak i u najprimitivnijim jezicima, riječi rijetko imaju prepoznatljivu sličnost s onime što označuju; nisu ništa više od konvencije. Dakako, to pripada tendenciji da se zbilja vidi simbolički, što je Cioran nazivao «ljepljivom simboličkom mrežom» jezika, beskonačnom regresijom koja nas odvaja od svijeta" (Zerzan 2004: 47).

${ }^{8}$ O tijelu pjesme bit će riječi u trećem poglavlju teksta. 
povezuje živo i mrtvo9: mrtva biljka u pustinji otvara se izbacujući sjeme na vlažnu zemlju, stoga je u funkciji života, „čežnju” u Rg Vedi X, 129, „,dok još nije bilo ničeg, ni nebitka ni bitka, bilo je Jedno”, „Čežnja se najprije pokrene u njemu”, potom „težnju” u egipatskoj kozmogoniji „Božanski iskonski duh nerazdvojiv od tvari pratekućine, osjetio je težnju za stvaralačkim djelom, a njegova je riječ probudila svijet u život" te uz to Paulingov zakon biologije „Život nije svojstvo nijedne molekule, nego je odnos među njima” (Pansini 1988: 36). Ako su čežnja i ljubav bili prvotni pokretači, svjetska pravolja, poriv za životom, onda je u razotkrivenoj naravi suvremene kulture očita tendencija tu binarnost razdvojiti te brojiti učinke restringiranja tijela: svođenja tijela na medij, stroj, prerastanje tijela u objekt žudnje bez ljubavi ${ }^{10}$.

Verbotonalna metoda nalazi vezu tijela, jezika i govora ${ }^{11}$ - koncepciju tjelesnosti slušanja i govora: ,cijelo tijelo sluša, cijelo tijelo govori, a usklađeno je sa svijetom i sa svijetom čini cjelinu" (Pansini 1985: 37).

9 „Stanice koje u sebi imaju jednak genetski kod razvijaju se u razna tkiva i stvaraju organe komunikacijom među stanicama, a zajedno vođene organogenezom. Organi su sastavljeni od stanica organiziranih u tkiva; organizam je organiziran komunikacijom. U morfogenezi oblikovanja uda bitan je proces smrt nekih stanica, proces koji je strogo određen u prostoru i vremenu, jer se drugačije ne bi mogao razviti predviđeni oblik organa. Tako je i s jedinkama: osim programa za održavanje života i vrste, nose u sebi i program samouništenja, starost kao bolest, rak, autoimune bolesti, programe koji su u funkciji vrsta, žrtvujući jedinku, a i u funkciji ekološke ravnoteže" (Pansini 1985: 36).

10 „Svršeno je s «erogenim zonama»: sve postaje rupa i nudi se refleksnom olakšanju. A naročito (kao u primitivnom inicijacijskom mučenju, koje nije naše), cijelo tijelo postaje znak i nudi se razmjeni znakova tijela" (Paić 2009: 273).

11 „Nerazdvojiv odnos tjelesnog i jezičnoga, tijela spram jezika i čina spram govora, nahodi se u središtu temeljnoga mita iz kojeg se razvila psihoanaliza - tragedija kralja Edipa. Kad Edip proklinje Lajova ubojicu, a zbor je mišljenja da nitko neće umaći tom prokletstvu, jer nitko - uključujući i ubojicu - neće biti lišen straha od njega, Edip pita, jer nije siguran: Hoće li se strašiti riječi, onaj tko se ne straši čina?" (Kristeva 1989: 99).

„Verbotonalna metoda je dio verbotonalnog sistema akademika Petra Guberine, pod kojom podrazumijevamo metodske pristupe i postupke koje koristimo u dijagnostici i rehabilitaciji slušanja i govora i u terapiji govornih poremećaja, neovisno o etiologiji i karakteru oštećenja te kronološkoj dobi pacijenta. Na jedinstvenim temeljnim principima i osnovnim postavkama razrađen je niz dijagnostičkih instrumenata i programa rehabilitacije primjerenih vrsti i broju oštećenja, te dobi pacijenta. Najčešća i najrasprostranjenija primjena verbotonalne metode u svijetu odnosi se na program rehabilitacije djece oštećena sluha i govora, odnosno poticanja razvoja govora i tada kada je sluh neoštećen" (Pansini 2013). 


\section{Od glasa do glasovne metafore: metaforička suvislost tijela (i) pjesme}

Fleksibilnu stabilnost označitelja i pojma, u potrazi za novim iskaznim mogućnostima, gramatičkim relacijama, zaziva tijelo u novom značenju/ razini, a metaforički princip kao djelatna snaga jezika omogućuje preoznačavanje, kao i proizvodnju novih značenja (cf. Biti, Marot Kiš 2008: 44). Svoj iskustveni svijet, iskustvo tijela i njegove smrtnosti (već smo spomenuli kako je smrt jezikom neprikaziva, ali je jezični paralelizam živoga i mrtvoga te tijelo stavljeno u prvi plan svojom smrtnošću oponaša) spoznajemo putem temeljnih pojmovnih metafora u diskursu pjesme u kojem se odvija metaforičko preslikavanje u procesima pojmovnog stapanja različitih mentalnih prostora. Tekstualni svijet pjesme spoznajno gradimo u vremenskoj dimenziji tijekom čitanja, u prostornoj dimenziji kao umjetničku sliku i kao prostor tijela pjesme. Ti su prostori u ovoj pjesmi stupnjevani, baš kao i glagoli, redoslijedom tjelesnog umiranja: „u mraku”, „kroz šiprag”, „u grmu”, „u lijesi”, „tišinom”, „kroz zvijezde”. Pjesma nam svojim naslovom $U$ vrtu priziva mjesto koje vrvi od života, a posljednjim stihom, uz prethodno stupnjevane glagole koji se odnose na ljudsko tijelo (,slušaj”, „,miruj”, ,ćuti”, „diši”, „drčći”, ,umri”), otkriva dijalog smrti (tijela) i života (ljubavi) kao ono u što pjesma tematski uranja te tako nametnutu koncepciju povezujemo u metaforičku suvislost cijelog teksta. Aliteracijska os glasova š i m značajna je jer prikazuje dijalog smrti i ljubavi koji je u posljednjem stihu doveden do kraja, a suprotnost vođena aliteracijskom osi glasova š i m maksimalno je na kraju pjesme izoštrena parovima riječi: ,umri dušo”, ,smrt” i „ljubav”.

Prostor pjesme je i tišina. Bijela margina koja odjekuje, ,praznina” i „ništa” o kojima govori Julia Kristeva analitički pristupajući Célineovim djelima: „Upravo na tom mjestu, gdje se emocija preobraća u zvuk, na spoju između tijela i jezika, u katastrofalnom preklapanju između jednoga i drugoga, tada iskrsava «moja velika protivnica, svirka». No, u stvarnosti taj se pomak uzbuđenja prema glazbi i muzici u krajnjoj liniji završava prazninom” (Kristeva 1989: 217). Tišinu, kao bolje rješenje od jezika, podupire J. Zerzan: „Propadanje jezika odražava općenitije otuđenje; jezik nam je postao gotovo potpuno izvanjski. Od Kafke do Pintera, upravo je tišina prikladan jezik našeg vremena"12 (Zerzan 2004: 56).

12 Ronald D. Laing dobro je to izrazio: „Rijetko se kojoj knjizi može oprostiti. Crna boja na platnu, tišina na ekranu, prazan bijeli list papira, to je još podnošljivo" (Zerzan 2004: 56). 
Vokativ „dušo” moguće je protumačiti sinegdohalnim prijenosom čitave pjesme na njen epiforički ${ }^{13}$ dio. Riječ se ponavlja 6 puta, takvim se ponavljanjem stvara zatvoreni prostor - prostor pjesme, a ponavljanje je, uz blizinu, osnovno načelo građenja pjesničkog teksta, ponavljanje uvijek upućuje na nešto.

U mraku žubor, vrelo - slušaj, dušo:

To izvor mog života romori;

Kroz šiprag hihot, vile - miruj, dušo:

To moja sreća tebi govori;

U grmu prvi slavuj - ćuti, dušo:

To moje srce tebi biljiše;

U lijesi prvo cvijeće - diši, dušo:

To moja duša tobom izdiše;

Tišinom struje, sjene - dršći, dušo:

To mjesec - zanos - k nama silazi;

Kroz zvijezde čežnje, slutnje - umri, dušo:

To smrt i ljubav k nama prilazi

(U vrtu, Matoš 1996: 27).

Govoreći o glasovnim vezama unutar pjesničkog teksta Vuletić ističe:

Osnovni i uvijek prisutan sadržaj glasovnih veza ostvarivanje je unutarnje motiviranih odnosa među riječima jednakog ili sličnog glasovnog sastava. Značajka unutarnje motiviranosti je povezivanje, poistovjećivanje različitih sadržaja preko jednakog, djelomično jednakog ili sličnog glasovnog sastava (Vuletić 2005: 101).

Ponavljanje glasa $\breve{s}^{14}$ (glas $\breve{s}$ ponavlja se 13 puta u pjesmi) motivirano povezuje riječi: „dušo”, „slušaj”, „diši”, ,izdiše” i upućuje na vezu tijeloživot-smrt: „dušo” nas upućuje na život, ,slušaj” i ,diši” na tijelo, a ,izdiše” na smrt. Veza glagola „ćuti” (koji upućuje na osjećaj) i glagola „diši”,

${ }^{13}$ Epifora je stilska figura u kojoj se ponavlja ista riječ ili iste riječi na kraju stihova (Klaić 1990: 382).

${ }_{14}$ Ovdje možda ne možemo govoriti o izrazitoj aliteraciji jer od ukupno 293 glasa koji čine pjesmu 13 ih je glas š. Međutim, od ukupno 12 stihova, samo 4 stiha ne sadrže glas š. 
„slušaj”, „dršći” (koji upućuju na osjetila), aliteracijom glasa š uspostavlja odnos osjećaj-osjetilo-tijelo.

Ponavljanje glasova $\mathrm{m}$ i r upućuje na motiviranu povezanost riječi: „,mraku”, „,romori”, „miruj”, „grmu”, „umri”, „smrt”. Glas m najniži je glas ljudskog govora. U ovoj se pjesmi glas m ponavlja 15 puta, što iznosi $5,11 \%$ od ukupnog broja glasova. U sinkraziji s aliteracijom glasa $r$ sintetizira smrt zatvarajući je u čvrstu motiviranu vezu glasova. Aliteracija glasa $r$ iznosi 6,8\% od ukupnog broja glasova (pjesma sadrži 293 glasa, a očekivana učestalost glasa $\mathrm{r}$ u neutralnom kontekstu iznosi 3,8-4,53\%). Ta aliteracija sinteze smrti proširuje dijalog život - smrt, te tako stoji naspram riječi „dušo” - nositelja suprotnosti, drugoj strani krajnosti ljudskog postojanja. Pjesma završava stihom koji sažimlje dijalog ljubavi i smrti vođen čitavom pjesmom: „To smrt i ljubav k nama prilazi”. „Romori” i „tišinom” dvije su riječi koje prikazuju dvije istaknute aliteracije (aliteraciju glasa š i glasa r), stoga nas okomica ovih dviju aliteracija upućuje na opoziciju dviju skupina riječi koje međusobno imaju čvrstu glasovnu vezu: „slušaj”, „dušo”, „,biljiše”, „diši”, „dršći” koje se vezuju uz život i „mraku”, „miruj”, „,umri”, ,smrt” koje se vezuju uz smrt.

\section{Od glasa do prostora pjesme}

Vraćajući se na već pročitani tekst, koji je obavio svoju prvotnu informacijsku funkciju, stvaramo prostor pjesme, motiviranim unutarnjim vezama spajamo stihove u novu cjelinu, u novo tijelo. Riječi u kojima uočavamo ponavljanje glasa $\mathrm{m}$ počinju nalikovati jedna na drugu, na svoj kontekst ${ }^{15}$, prostor se počinje stvarati, prostor u kojem dimenzije postaju nebitne, a odnosi među glasovima i riječima najbitniji, jer su oni (odnos i prostor) u uzajamnoj egzistentnoj sprezi. I boje i glasovi fizikalno su kontinuirani, ali mi ih prepoznajemo i razlikujemo; doživljavamo ih u omeđenom prostoru, prilagođavamo ih svom prostoru. Kako bi usvojio govor, i gluh i čujući čovjek ima isti put: „od događaja preko spaciocepcije do predodžbe, uvida govora

15 Jezični znak opisuje vanjski svijet nastojeći što manje nalikovati tom svijetu, jer se tako postiže efikasnost komunikacije: tek tako se oblikuje kreativni govor kojim se izražavaju misli, kojim se opisuje i interpretira, a ne samo imitira stvarnost. Pjesnički znak stvara svoj vlastiti svijet nastojeći što više nalikovati svom kontekstu, tj. nastojeći uspostaviti što više materijalnih veza sa svojim kontekstom (Vuletić 2013). 
i mišljenja" (Pansini 1988: 125). Gramatiku jezika, gramatiku govora, gramatiku tijela i gramatiku pjesme veže neodvojivost od prostora - spacijalnost. Bez prostora one ne bi postojale niti se razvijale ${ }^{16}$. Poznato je da sve što nalazimo u jeziku ne pripada samo jeziku, pa se mnogi principi njegova funkcioniranja mogu tumačiti kao preslika općih zakona svemira.

Vokativ „dušo” koji najistaknutije, pomognut stilskim postupkom epiforizacije, diže okomicu s desne strane tijela pjesme, ovdje nosi svoju invokacijsku, primarnu funkciju, no je li to njegova jedina uloga u ovome zatvorenom prostoru tijela pjesme? Vokativ ima i ekspresivnu (izražavanje osjećaja ili stava prema sugovorniku), komunikacijsku te konativnu (apelativnu) funkciju - jezičnim sredstvima vokativom i imperativom nastoji se izazvati reakcija sugovornika. Matoš izražava svoje osjećaje, nastoji isprovocirati svog sugovornika - (svoju vlastitu) dušu. Međutim, duša šuti, ne uzvraća mu niti jednom riječju, tek zadnjim stihom:

„To smrt i ljubav k nama prilazi” pojašnjava povratak u živo, ali smrtno tijelo. O stalnoj izmjeni ciklusa život/smrt/život govori Pincola Estés kao o prirodi ljubavi, ciklusu oživljavanja koji utječe na sve: „Sve - sunce, mjesec, kao i ljudske stvari i stvari najsitnijih stvorenja, kao što su stanice i atomi - poznaje to treperenje, posrtanje, pa ponovno treperenje" (Estés 2007: 149).

Sličan postupak prethodnomu - uočavanje prostora pjesme - nalazi Julia Kristeva analizirajući Célineove tekstove u kojima „bijeg od rečenice” predstavlja ,nadsintaksu” kojom se pak potisnutim strategijama iskaza postiže uzbuđenje. Isto ono što uočava Kristeva u Célineovu tekstu u našem (Matoševu) slučaju izdvojeni je dio stihova - „dušo" - koji svojom epiforičnošću upućuje na postupak ponavljanja kao postupak desintaktiziranja kojemu pridonosi hotimična emfatičnost. Potisnutu strategiju iskaza Kristeva objašnjava pojačanom upotrebom konstrukcije tema/rema u prvim fazama učenja sintakse kod djece, koja se podudara s autonomizacijom, uviđanjem vlastitog identiteta. Ovaj Célineov postupak Kristeva ističe kako Célineovo govorno nastoji potisnuti jezično: „Uzbuđenje se može zahvatiti i prenijeti samo kroz govorni jezik” (Kristeva 1989: 218). Škarić, objašnjavajući unutarnji govor (subvokalizaciju) koji ima

${ }^{16}$ Fridrich je, analizirajući sufiksalni sustav u jeziku taraskana (jugozapadni Meksiko), pokazao kako prostorna konfiguracija čovjekova tijela služi kao prototip osmišljavanja niza konkretnih i apstraktnih pojava i dobiva u jeziku gramatički izraz (Piper 2001: 27). 
sve osobine govora, zvučnost i mišićnu aktivnost, potvrđuje tu neizbježnost govora - dok šutimo, mi govorimo (Škarić et al. 1991: 72). Možda je to onaj govor iz vremena za kojim čeznemo, iz starog sna o lingua Adamici, o jeziku koji bi izražavao izravno značenje stvari, naš unutarnji govor kao dio čežnje čovječanstva za bliskijim odnosom prema drugim ljudskim bićima i prema prirodi.

Duboka se istina krije u shvaćanju da „ljubavnicima ne trebaju riječi”. Radi se o tome da moramo ostvariti svijet ljubavnika, svijet odnosa „licem u lice”, u kojemu se mogu zaboraviti čak i imena, svijet koji zna da je suprotnost neznanju - očaranost. Smisla ima samo ona politika koja poništava jezik i vrijeme, te je stoga vizionarska do stupnja strastvenosti (Zerzan 2004: 57).

\section{Literatura}

Biti V., 1994, Upletanje nerečenog, Zagreb.

Biti M., Marot Kiš D., 2008, Poetika uma - osvajanje, propitivanje i spašavanje značenja, Zagreb.

Debord G., 1999, Društvo spektakla, prev. G. Vujasinović, Zagreb.

Dolar M., 2009, Glas i ništa više, prev. A. Ryznar, Zagreb.

Klaić B., 1990, Rječnik stranih riječi, Zagreb.

Kristeva J., 1989, Moći užasa, prev. D. Marion, Zagreb.

Matoš A.G.,1996, Izabrane pjesme, Zagreb.

Paić Ž., 2009, Zaokret spram tijela, „Zeničke sveske” br. 9, str. 267-279.

Pansini M., 1985, Volja, komunikacija, jezik, „Republika” br. 5, Zagreb, str. 35-49.

Pansini M., 1988, Koncept gramatike prostora, „Govor” br. 5, Zagreb, str. 117-128.

Pansini M., 2013, osobna stranica Mihovila Pansinija na www.suvag.hr, <http://www. suvag.hr/ mpansini > , 20.10.2013.

Pincola Estés C., 2007, Žene koje trče s vukovima, prev. L. Holbling Matković, Zagreb.

Piper P., 2001, Jezik u prostoru i prostor u jeziku, Beograd.

Škarić I. et al., 1991, Povijesni pregled, glasovi i oblici hrvatskoga književnog jezika, Zagreb.

Vuletić B., 2005, Fonetika pjesme, Zagreb.

Vuletić B., 2007, Lingvistika govora, Zagreb.

Vuletić B., 2013, Prostor pjesme i prostor pjesništva, <http://www.hrvatskiplus.org/ index.php?option $=$ com_content $\&$ view $=$ article $\& \mathrm{id}=318$ : vuletic-prostor $\&$ catid $=37$ : meandri-pjesnistva\&Itemid $=71>, 02.08 .2013$.

Zerzan J., 2004, Anarhoprimitivizam protiv civilizacije, prev.V. Kirinić, I. Grbić, Zagreb. 